\title{
ZONING OF ENVIRONMENTAL CONDITIONS INSIDE A WEAN-TO-FINISH PIG \\ FACILITY
}

Doi:http://dx.doi.org/10.1590/1809-4430-Eng.Agric.v36n5p739-748/2016

\section{JULIANA M. MASSARI ${ }^{*}$, DANIELLA J. DE MOURA ${ }^{1}$, THAYLA M. R. DE C. CURI' RIMENA DO A. VERCELLINO ${ }^{1}$, BRENDA B. L. MEDEIROS ${ }^{1}$}

\begin{abstract}
Using geostatistics, this study aimed to analyze environmental conditions for weanto-finish swines at $3 \mathrm{pm}$, during the most sensitive phases to thermal stress (growth/ finishing and finishing). To this end, dry-bulb temperature, relative humidity, air speed, ammonia and carbon dioxide concentrations were measured at 81 equidistant points within the barn. Descriptive statistics was used to classify attribute variability, generating mean, median, variation coefficient, asymmetry and kurtosis, through the normality of Kolmogorov-Smirnov (KS). For that, it was used Minitab 15 software. Moreover, semivariograms were used to assess spatial dependence using the GS+ software, and through Surfer, spatial distribution maps were designed. Dry-bulb temperature and relative humidity showed a more homogeneous distribution whether compared to the other attributes. Furthermore, critical points were observed within the facility, with temperatures and low humidity, indicating the need for fogging equipment and fans to improve thermal comfort and animal welfare.
\end{abstract}

KEY WORDS: ambience, welfare, geostatistics, pig farming

\section{INTRODUCTION}

Brazil is the fourth largest producer and exporter of pork worldwide, rearing pigs under intensive feedlot conditions, to optimize production and economic performances (BAPTISTA et al., 2011). Constant and growing consumer concerns about animal welfare and rearing conditions have boosted the search for sustainable social-friendly production systems (SARUBBI et al., 2010).

In conventional swine rearing systems, animals are housed in separate facilities, according to age and type. In contrast, in wean-to-finish systems, animal flow is held within the same facility from weaning to slaughter (MEDEIROS et al., 2014). Nevertheless, studies on environmental quality, weight gain, sexing, and animal welfare for this system are still scarce.

Environmental factors (air temperature, relative humidity, air speed, illuminance, radiation, among others) have an influence on animal thermoregulation (CAMPOS et al., 2008; AMARAL et al., 2011). Yet concentration of gases, primarily ammonia and carbon dioxide, interfere with air quality inside animal facilities, since low levels enhance yield and reduce disease risks (PANDORFI et al., 2012).

Unfavorable climatic conditions are limiting to achieve maximum productivity, particularly in growing and finishing swines, wherein sensitivity to heat is strengthened, thus using breath as heat dissipation mechanism to prevent internal heating (RODRIGUES et al., 2010). Therefore, environmental monitoring is critical to making decisions on corrections or adjustments to be made in animal husbandry facilities, developing then an effective program to fix each issue raised (SALES et al., 2011). In order to understanding the control of the generated environment by facility type, micrometeorology and ventilation system, several computational tools can be used (fluid mechanics, Fuzzy logic, data mining).

Geostatistics is one of the tools that enable deepening on the knowledge of the factors interfering with the rearing environment, providing the highest accuracy in corrections and adjustments of the farming systems (ABREU \& ABREU, 2011; CARVALHO et al., 2012). The

\footnotetext{
${ }^{1}$ Faculdade de Engenharia Agrícola - UNICAMP/Campinas-SP, Brasil.

*Corresponding author. E-mail: jujumassari@ hotmail.com

Received in: 1-5-2016

Accepted in: 5-4-2016
} 
results can also be interpreted by natural variability that is, making the use of spatial dependence modeling for each variable through semivariance. Thus, spatial variability maps could disclose that analyzing a single point might be not enough, under- or over-estimating such value (SILVA et al., 2013; NÄ̈̈S, 2011). Several authors have reported the use of geostatistics in animal husbandry (CURI et al., 2014; MEDEIROS et al., 2014; SILVA NETO et al., 2011). Given the above, this study aimed to identify different environmental zones within a pig rearing facility of a wean-tofinish system during growing to finishing and finishing phases, by making use of geostatistics.

\section{MATERIAL AND METHODS}

The experiment was carried out in a commercial swine facility in Joaçaba city, Santa Catarina

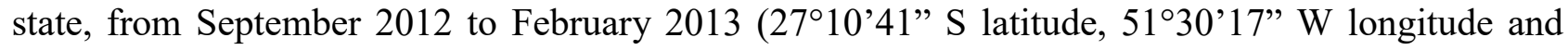
$522 \mathrm{~m}$ altitude). Local weather is predominantly humid subtropical, Cfa type as Köppen's classification. A mixed batch of 301 piglets of a commercial lineage (Large White $\mathrm{x}$ Agroceres) was housed in the barn. Weaning occurred on average at 28 days of age when animals had a mean weight of $7.5 \mathrm{~kg}$. Pigs for slaughter were weighing approximately $120 \mathrm{~kg}$. Barn facility had the following measures: $9.50 \mathrm{~m}$ width, $42.00 \mathrm{~m}$ length, and $3.00 \mathrm{~m}$ ceiling height with a north-south runway. Lateral and ceiling insulations were made with yellow polypropylene drapes, and gable roof covered with pottery tiles with $0.60-\mathrm{m}$ eaves. Roof framework was built with pinewood. The facility structure was composed of masonry pillars on the outside and wood on the inside. Lawns and fruit trees composed the facility surroundings, shading certain areas inside the barn (Figure 1).

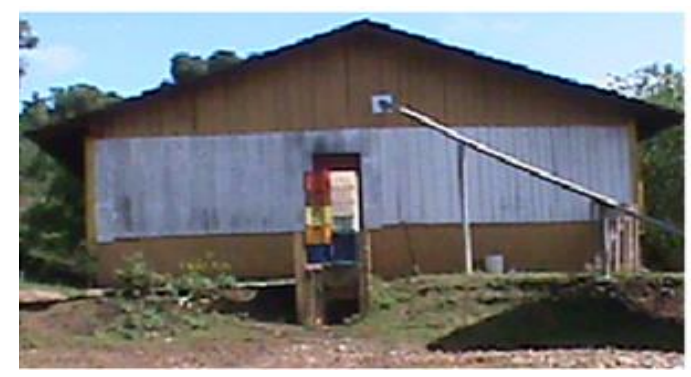

(a)

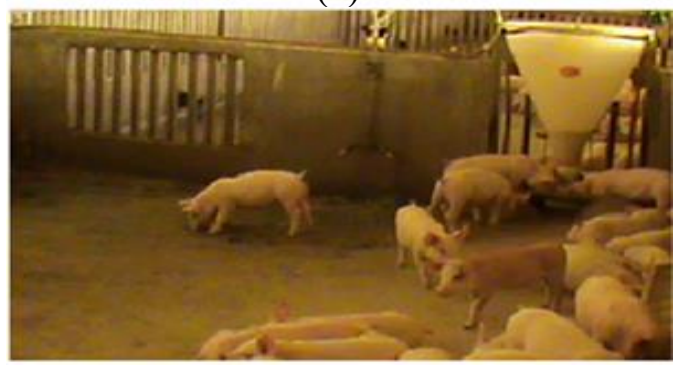

(c)

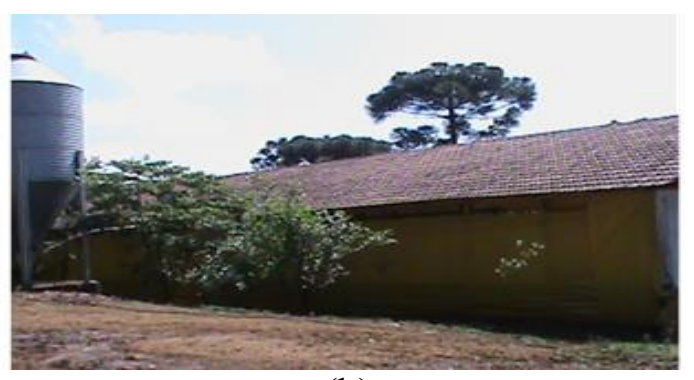

(b)

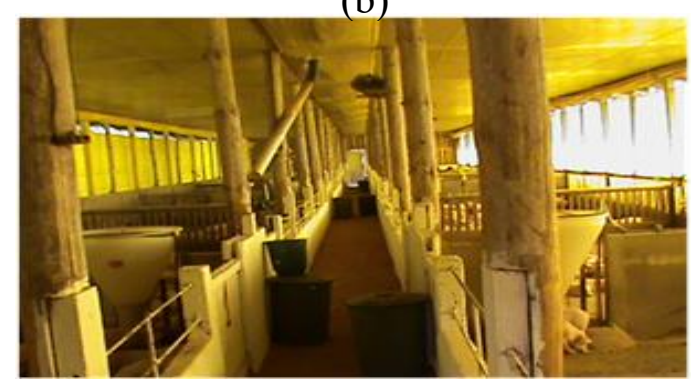

(d)

FIGURE 1. Wean-to-finish facility used in this experiment: (a) Frontal view; (b) Lateral view; (c) Stall interior; and (d) Barn interior.

The facility had 12 sow stalls separated by $1.0 \mathrm{~m}$ masonry walls of hollow blocks. Each stall had a cement floor area of $24.64 \mathrm{~m}^{2}(6.40 \mathrm{~m} \times 3.85 \mathrm{~m})$ plus a $0.95 \mathrm{~m}$ corridor in the middle of the barn. There were also two auxiliary stalls (AS) with walls of $1.00 \mathrm{~m}$ in height and floor area of 4.89 $\mathrm{m}^{2}(1.27 \mathrm{~m} \times 3.85 \mathrm{~m})$.

The stalls were equipped with a semi-automatic feeder, two drinking troughs and one dual nipple-type drinkers with height adjustment. The facility ventilation system was the natural type with adjustable wall drapes.

The barn was divided into 81 equidistant points (9 lines x 9 columns) to record environmental data above animals (1.50 $\mathrm{m}$ from the floor) (TOLON et al., 2010) (Figure 2). Hence, we registered 
data on dry bulb temperature $\left(\mathrm{T}_{\mathrm{db}}\right)$, relative humidity $(\mathrm{RH})$, air speed $\left(\mathrm{S}_{\mathrm{air}}\right)$, besides the concentrations of ammonia $\left(\mathrm{NH}_{3}\right)$ and carbon dioxide $\left(\mathrm{CO}_{2}\right)$.

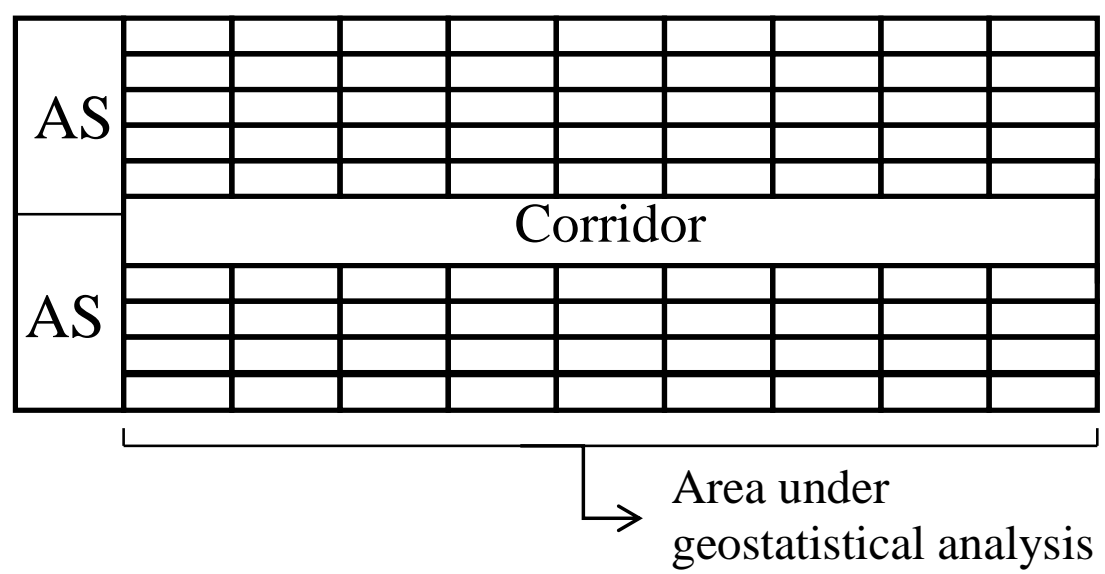

FIGURE 2. Diagram of the distribution of points to record the environmental variables for geostatistical analysis.

Records of $\mathrm{T}_{\mathrm{db}}\left({ }^{\circ} \mathrm{C}\right)$ and $\mathrm{S}_{\mathrm{air}}\left(\mathrm{m} \mathrm{s}^{-1}\right)$ were taken by a hot wire anemometer with reading scale for temperature between -18 to $93{ }^{\circ} \mathrm{C}$, and resolution of $0.1{ }^{\circ} \mathrm{C}$, and air speed amplitude from 0 to $30 \mathrm{~m} \mathrm{~s}^{-1}$, resolution of $0.01 \mathrm{~m} \mathrm{~s}^{-1}$ and accuracy of $\pm 0.015 \mathrm{~m} \mathrm{~s}^{-1}$. For RH records, a THDL 400 equipment was used within an amplitude range of $25-95 \%$, and accuracy of $\pm 5 \%$. The data regarding the concentrations of $\mathrm{NH}_{3}(\mathrm{ppm})$ and $\mathrm{CO}_{2}(\mathrm{ppm})$ were gathered by means of an instant gas concentration meter. All the data were measured at $9 \mathrm{am}, 12 \mathrm{pm}$ and $3 \mathrm{pm}$ to a height of 1.0 meter from the floor, however, in this paper are only expressed the outcomes taken at $3 \mathrm{pm}$, since it was the most critical time.

The variability of the attributes was verified based on descriptive statistics of the data recorded $\left(\mathrm{T}_{\mathrm{db}}, \mathrm{RH}, \mathrm{S}_{\mathrm{air}}, \mathrm{CO}_{2}\right.$ and $\left.\mathrm{NH}_{3}\right)$, The variability of the attributes has been verified based on descriptive statistics data recorded, obtaining means, medians, coefficients of variation and the normality by Kolmogorov-Smirnov's test, as describe in MEDEIROS et al. (2014). The spatial dependence is given by semivariogram fitting (VIEIRA, 2000), based on stationarity of the intrinsic hypothesis, which is estimated by [eq. (1)].

$$
\hat{\gamma}=\frac{1}{2 N(h)} \sum_{i=1}^{N(h)}\left[Z\left(x_{1}\right)-Z\left(x_{1}+h\right)\right]^{2}
$$

In which,

$\mathrm{N}(\mathrm{h})$ - number of experimental pairs;

$\mathrm{Z}\left(\mathrm{x}_{1}\right)$ and $\mathrm{Z}\left(\mathrm{x}_{1}+\mathrm{h}\right)$ - observations distant in $\mathrm{h}(\mathrm{m})$.

The experimental semivariogram is represented by the graph of semivariance as function of $h$. The coefficients of theoretical model are estimated from a mathematical model fit to the semivariance values (nugget effect $-\mathrm{C}_{0}, \mathrm{~m}$; sill, $\mathrm{C}_{0}+\mathrm{C}_{1}, \mathrm{~m}$; and range, a, $\mathrm{m}$ ). Spatial dependence degree (SDD) of the attributes was assigned by means of the classification proposed by CAMBARDELLA et al. (1994), in which strong SDDs are semivariograms with C0<25\% sill, moderate when it is between 25 and $75 \%$ and weak for values $>75 \%$.

Semivariogram examination was made to test spatial dependence presence. Spatial distribution mapping was performed with the aid of a software which allowed designing isoline maps for regionalized variables of interest $\left(\mathrm{T}_{\mathrm{db}},{ }^{\circ} \mathrm{C} ; \mathrm{RH}, \% ; \mathrm{S}_{\mathrm{air}}, \mathrm{ms}^{-1}, \mathrm{NH}_{3}, \mathrm{ppm} ; \mathrm{CO}_{2}, \mathrm{ppm}\right)$. Aiming to facilitate spatial dependence comparisons among the variables under study, the $\mathrm{C} 0$ was expressed as a percentage of sill (TRANGMAR et al., 1985). 


\section{RESULTS AND DISCUSSION}

Table 1 shows descriptive statistics regarding the environmental variables inside the pig rearing facility for growing/ finishing $(\mathrm{G}+\mathrm{F})$ and finishing $(\mathrm{F})$ phases.

TABLE 1. Descriptive statistics of the environmental data recorded inside the facility for wean-tofinish pig farming system, during growing/ finishing and finishing phases.

\begin{tabular}{llllllll}
\hline Variable & Phase & Minimum & Maximum & Mean & Median & CV & KS \\
\hline $\mathrm{T}_{\mathrm{db}}\left({ }^{\circ} \mathrm{C}\right)$ & $\mathrm{G}+\mathrm{F}$ & 28.90 & 32.50 & 30.36 & 30.15 & 2.81 & 0.03 \\
& $\mathrm{~F}$ & 31.80 & 35.70 & 33.30 & 33.15 & 3.19 & $0.07^{\mathrm{ns}}$ \\
$\mathrm{RH}(\%)$ & $\mathrm{G}+\mathrm{F}$ & 28.30 & 42.90 & 33.97 & 32.90 & 11.94 & 0.01 \\
& $\mathrm{~F}$ & 26.90 & 33.60 & 29.32 & 29.13 & 3.82 & $0.15^{\mathrm{ns}}$ \\
$\mathrm{S}_{\text {air }}\left(\mathrm{m} \mathrm{s}^{-1}\right)$ & $\mathrm{G}+\mathrm{F}$ & 0.00 & 1.60 & 0.52 & 0.35 & 83.92 & 0.01 \\
& $\mathrm{~F}$ & 0.10 & 0.80 & 0.34 & 0.35 & 46.51 & $0.15^{\mathrm{ns}}$ \\
$\mathrm{CO}_{2}(\mathrm{ppm})$ & $\mathrm{G}+\mathrm{F}$ & 0.00 & 350.00 & 108.80 & 112.50 & 80.23 & 0.03 \\
& $\mathrm{~F}$ & 0.00 & 250.00 & 98.92 & 137.50 & 67.82 & 0.01 \\
$\mathrm{NH}_{3}(\mathrm{ppm})$ & $\mathrm{G}+\mathrm{F}$ & 0.00 & 4.00 & 1.95 & 2.00 & 56.47 & $0.15^{\mathrm{ns}}$ \\
& $\mathrm{F}$ & 0.00 & 2.00 & 0.38 & 0.00 & 145.00 & 0.01 \\
\hline
\end{tabular}

$\mathrm{CV}=$ coefficient of variation $\%, \mathrm{KS}=$ normality of Kolmogorov-Smirnov; ns= non-significant by the Kolmogorov-Smirnov's test; $\mathrm{T}_{\mathrm{db}}=$ dry-bulb temperature; $\mathrm{RH}=$ relative humidity; $\mathrm{S}_{\mathrm{air}}=$ air speed $; \mathrm{CO}_{2}=$ concentration of carbon dioxide; $\mathrm{NH}_{3}=$ concentration of ammonia; $\mathrm{G}+\mathrm{F}=$ growing/ finishing; $\mathrm{F}=$ finishing.

The recorded $\mathrm{T}_{\mathrm{db}}$ values indicate that pigs were under thermal stress in both phases, hindering a maximum performance and animal welfare since they went above the range of 18 to $23^{\circ} \mathrm{C}$, as well as above the critical maximum of $27^{\circ} \mathrm{C}$ (SAMPAIO et al., 2004). It is because $\mathrm{T}_{\mathrm{db}}$ and $\mathrm{RH}$ are bioclimatic factors play a more important role in animal comfort (CASSUCE et al., 2013).

Thermal environment encompasses the joint effect of room temperature, solar radiation, air humidity and velocity (CORDEIRO et al., 2012); therefore, one can deduce that the natural ventilation system used by the farmer is not suitable to maintain temperatures within an appropriate range for pig rearing during the production phases analyzed.

Regarding the $\mathrm{RH}$, it is noteworthy that the average of $33.97 \%$ for $\mathrm{G}+\mathrm{F}$ and $29.32 \%$ for $\mathrm{F}$ were below optimal for comfort zone, which is between 40 to $70 \%$, with levels smaller than the minimum considered critical (SAMPAIO et al., 2004). MEDEIROS et al. (2014), studying the thermal environment for pigs reared in a wean-to-finish system, at different stock densities and at $\mathrm{F}$ phase, found a $\mathrm{RH}$ value of $40.44 \%$ at $3 \mathrm{pm}$, which is within the bearable range. Therefore, the found $\mathrm{RH}$ values highlight the evaporative cooling potential of the facility (CARVALHO et al., 2009), being advisable the installation of nebulizers and fans inside the barn to assist in heat loss.

When dealing with air quality, certain variables should be spotlighted as air speed and $\mathrm{CO}_{2}$ and $\mathrm{NH}_{3}$ gas concentrations, because they could display ventilation system effectiveness. This system, whether properly set, may enhance thermal comfort for swines, renewing the air, controlling gas and odor dissipation, moisture excess, aerosols, heat, and regulating animals' body temperature through convection. Conversely, unless properly operated, this variable may be responsible for increasing the levels of some air pollutants such as $\mathrm{NH}_{3}$ and $\mathrm{CO}_{2}$ what would be a critical factor (PANDORFI, 2012). The air speed measures within both phases were close to those found by SAMPAIO et al., (2006), with averages varying from 0 to $1.0 \mathrm{~m} \mathrm{~s}^{-1}$. The concentration of gases were also within the range recommended as ideal, with maximum of 3,000 and $20 \mathrm{ppm}$ for $\mathrm{CO}_{2}$ and $\mathrm{NH}_{3}$, respectively (GLOBALG.A.P., 2012), without harming animal's health.

The homogeneity analysis of climatic parameters is intended to ensure amenities in the environment regarding thermal and air factors, i.e., minimizing hot spots and poor air renewal (dead spaces) (BOURNET \& BOULARD, 2010). Thus, Table 1 shows, for both phases, that mean and median values are close, which states a data symmetrical distribution. 
Under Kolmogorov-Smirnov testing, all variables recorded inside the facility during $\mathrm{F}$ phase showed normal distribution. Another evaluation criterion concerns to the coefficient of variation, which was rated according to WARRICK \& NIELSEN (1980), taking into account low variability as $<12 \%$, mean variability between 12 and $24 \%$, and high variability $>24 \%$. For VANNI (1998), $\mathrm{CV}$ above $35 \%$ indicates a heterogeneous series and, consequently, the average has little significance; this happened for air speed and concentrations of $\mathrm{NH}_{3}$ and $\mathrm{CO}_{2}$, as seen in Table 1 .

Accordingly, the $\mathrm{T}_{\mathrm{db}}$ and $\mathrm{RH}$ showed low variability in both rearing phases, which indicates that the ventilation system and facility conditions were able to maintain a homogeneous distribution. In contrast, air speed and the concentrations of $\mathrm{NH}_{3}$ and $\mathrm{CO}_{2}$ showed high variability, which is attributed to the wide range of variation between minimum and maximum values, but also, because of the natural ventilation system used in the barn.

Concerning the air speed, MEDEIROS et al. (2014) also reported similar results, stressing such high variability as consequence of constant wind changes of magnitude and direction. Stall division walls are physical barriers preventing the passage of air, which would potentially affect the distribution of variables, mainly the air speed.

The geostatistics showed that the $\mathrm{T}_{\mathrm{db}}$, in both phases, and $\mathrm{RH}$, in $\mathrm{G}+\mathrm{F}$, were adjusted to a gaussian model. Nevertheless, an exponential model was adjusted for $\mathrm{RH}$, in $\mathrm{F}$, and for $\mathrm{CO}_{2}$ and $\mathrm{NH}_{3}$ concentrations, in $\mathrm{G}+\mathrm{F}$. Yet a spherical model fit was observed for air speed, in both phases, and for $\mathrm{NH}_{3}$ and $\mathrm{CO}_{2}$ concentrations in $\mathrm{F}$.

On analyzing the ratio $\mathrm{C}_{0} /\left(\mathrm{C}_{0}+\mathrm{C}_{1}\right)$, we can conclude that both climatic and air variables showed a strong spatial dependence. The higher the spatial dependence, the lower the contribution of the nugget effect on data variability, consequently, the better the kriging estimates for the construction of maps. Table 2 shows the models and parameters estimated by the semivariograms.

TABLE 2. Models and parameters estimated by the experimental semivariograms for the assessed environmental variables for wean-to-finish pig farming system, during growing/ finishing and finishing phases.

\begin{tabular}{lllllll}
\hline Variable & Phase & Model & Range & SDD & $\mathrm{R}^{2}$ & $\mathrm{RSS}$ \\
\hline \multirow{2}{*}{$\mathrm{T}_{\mathrm{db}}\left({ }^{\circ} \mathrm{C}\right)$} & $\mathrm{G}+\mathrm{F}$ & Gaussian & 10.27 & 96.87 & 0.948 & $4.41 \mathrm{e}-2$ \\
& $\mathrm{~F}$ & Gaussian & 36.92 & 95.97 & 0.986 & 0.0206 \\
$\mathrm{RH}(\%)$ & $\mathrm{G}+\mathrm{F}$ & Gaussian & 32.99 & 94.69 & 0.990 & $1.23 \mathrm{e}+1$ \\
& $\mathrm{~F}$ & Exponential & 10.62 & 88.76 & 0.878 & 0.0486 \\
$\mathrm{~S}_{\text {air }}\left(\mathrm{m} \mathrm{s}^{-1}\right)$ & $\mathrm{G}+\mathrm{F}$ & Spherical & 9.92 & 98.82 & 0.723 & $1.14 \mathrm{e}-2$ \\
& $\mathrm{~F}$ & Spherical & 12.92 & 86.06 & 0.648 & $1.76 \mathrm{e}-4$ \\
$\mathrm{CO}_{2}(\mathrm{ppm})$ & $\mathrm{G}+\mathrm{F}$ & Exponential & 19.83 & 93.72 & 0.868 & $3.20 \mathrm{e}+6$ \\
& $\mathrm{~F}$ & Spherical & 9.05 & 99.82 & 0.882 & 3840696 \\
$\mathrm{NH}_{3}(\mathrm{ppm})$ & $\mathrm{G}+\mathrm{F}$ & Exponential & 27.03 & 98.87 & 0.759 & $1.09 \mathrm{e}-1$ \\
& $\mathrm{~F}$ & Spherical & 14.13 & 96.00 & 0.975 & $2.66 \mathrm{e}-3$ \\
\hline
\end{tabular}

$\mathrm{SDD}=$ spatial dependence degree; $\mathrm{R}^{2}=$ coefficient of determination; $\mathrm{RSS}=$ residue sum of squares; $\mathrm{CO}_{2}=$ carbon dioxide concentration; $\mathrm{NH}_{3}=$ ammonia concentration; $\mathrm{G}+\mathrm{F}=$ growing/ finishing; $\mathrm{F}=$ finishing.

The range is the maximum distance over which the sampling units are not spatially correlated any longer; and it can be analyzed through classical statistics (VIEIRA, 2000). The longest range was seen for the variable $\mathrm{T}_{\mathrm{db}}(36.92 \mathrm{~m})$ in the phase $\mathrm{F}$, while the shortest was for $\mathrm{CO}_{2}$ concentration $(9.05 \mathrm{~m})$, also in F. All variables showed well-defined sills. The $\mathrm{R}^{2}$ values ranged from 0.723 to 0.990 , except for $S_{\text {air }}$ in $F$, which was below 0.75. Figure 3 displays the kriging map for environmental conditions inside the facility for wean-to-finish pig rearing in $\mathrm{G}+\mathrm{F}$. 


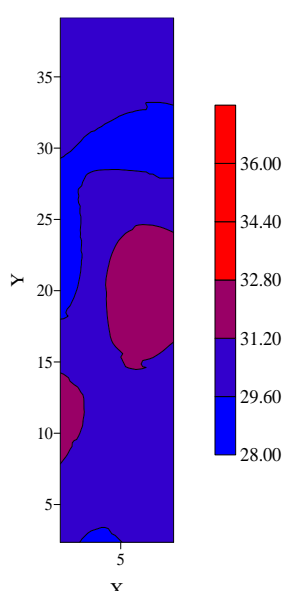

(a)

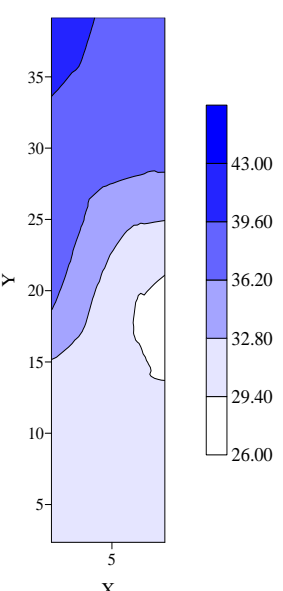

(b)

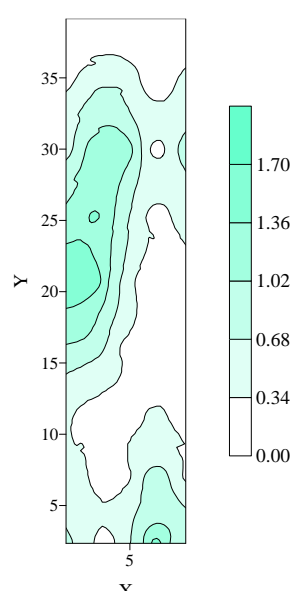

(c)

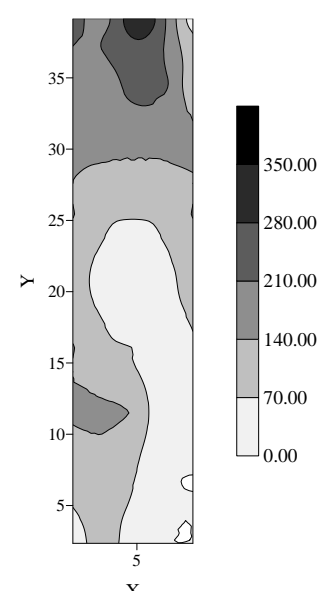

(d)

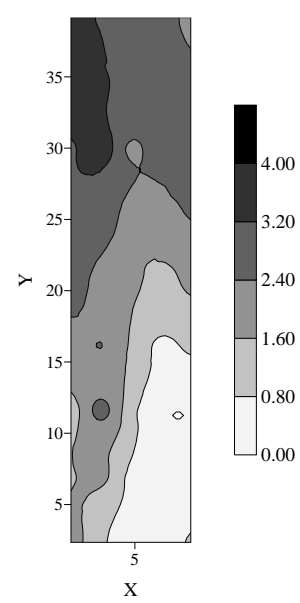

(e)

FIGURE 3. Kriging maps of environmental variables inside a pig rearing facility in growing/ finishing phase: (a) dry bulb temperature; (b) relative humidity; (c) air speed; (d) carbon dioxide concentration; and (e) ammonia concentration.

Figure 3 (a) highlights the center right side as the largest thermal discomfort region, and to a lesser extent to the left side. This finding might be due to the absence of fruit trees near the outside the facility, increasing sunlight incidence and hence the greatest heat gain. A small range of temperature near critical point $\left(28^{\circ} \mathrm{C}\right)$ is highlighted within the lower base of the graph, and another area of great extent involving the upper center right and extending to the left side. The other regions showed a homogeneous distribution, with an average $\mathrm{T}_{\mathrm{db}}$ of $29.60{ }^{\circ} \mathrm{C}$. It is worth mentioning that roof and wall quality were not similar, showing structural failures and lack of maintenance, since radiation increases heat gain.

By Figure 3 (b), it can be seen that RH behaved non-uniformly during phase G+F with critical value within a small portion on the right side region, near the center, just as it was for the highest $\mathrm{T}_{\mathrm{db}}$. Therefore, these variables are inversely proportional, a finding that was also emphasized by CARVALHO et al. (2012) and MEDEIROS et al. (2014). Moreover, RH remained within limits postulated in the literature only in the upper left region, emphasizing existing microclimates within this facility; furthermore, factors like air temperature, shadowing, stocking density, water consumption and wasting could interfere with this variable. Another point to be considered is time of day; BARACHO et al. (2008) found a significant difference in RH within daytime hours, which was not checked for seasons, when assessing a pig finishing facility.

Figure 3 (c) shows the presence of "dead spaces" in which air speed is zero, mainly in F phase (Figure 4-c) which had the worst thermal condition observed, not mitigating the thermal feeling above optimal, besides of a maximum value of $0.34 \mathrm{~m} \mathrm{~s}^{-1}$. However, there was greater variability of air speed in $\mathrm{G}+\mathrm{F}$, with higher values to the center left. Another aggravating factor for ventilation system is to be of natural type, favoring unevenness in air renewal; notwithstanding, uneven distributions were also found for bioclimatic variables in air conditioning systems (CURI et al., 2014).

$\mathrm{CO}_{2}$ was directly proportional to $\mathrm{NH}_{3}$ concentrations and inversely to air speed, as shown in Figure 3 (c) and (d). Gaseous emissions are positively related to temperature and ventilation rates (PHILIPPE \& NICKS, 2015) and, therefore, fans must be installed at strategic positions to assist air renovation as well as maintenance of its quality.

Figure 4 shows to the kriging map of environmental conditions inside a facility for wean-tofinish pig rearing during $\mathrm{F}$ phase. 


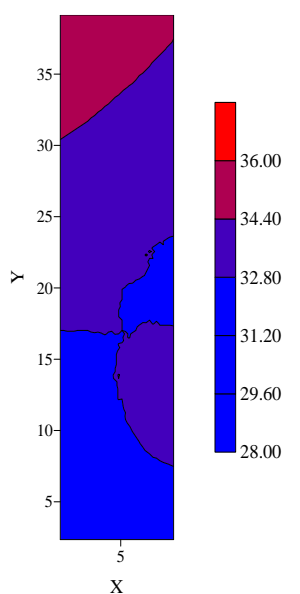

(a)

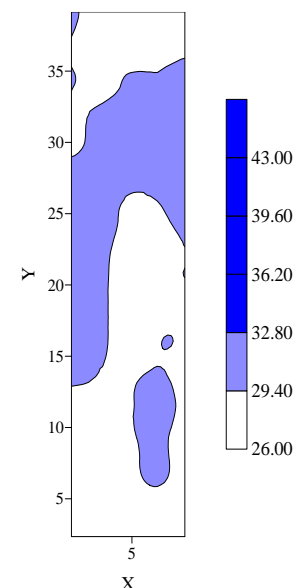

(b)

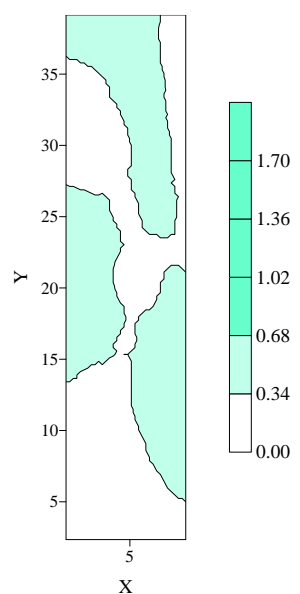

(c)

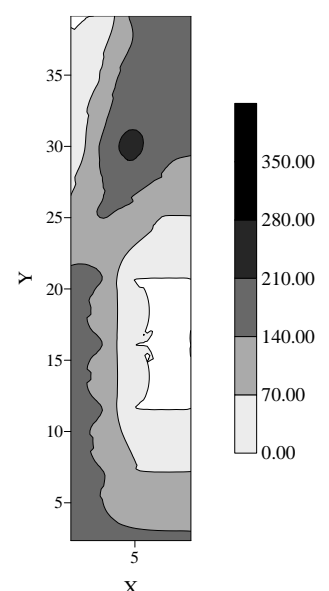

(d)

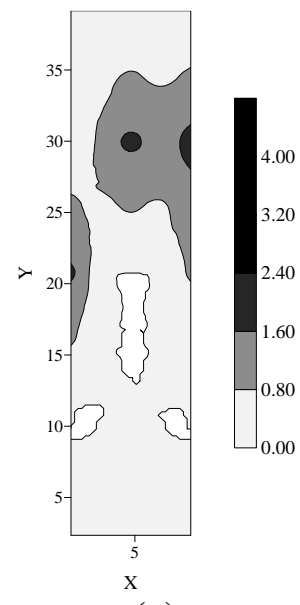

(e)

FIGURE 4. Kriging maps of environmental variables inside a pig rearing facility in finishing phase: (a) dry bulb temperature; (b) relative humidity; (c) air speed; (d) carbon dioxide concentration; and (e) ammonia concentration.

According to Figure 4 (a), milder temperatures are in the bottom, stretching to the central area of the barn, and largely than the last analyzed kriging map. Higher temperatures were only observed in the upper part. It is noteworthy that the side of the barn that had trees to the outside favored lower temperatures once it has minimized heat gain from direct radiation.

For HR (Figure 4b), it was found the worst environmental quality, and most of the facility presented a $\mathrm{RH}$ of $26 \%$, indicating again an evaporative cooling potential. Then, installing nebulizer lines inside the barn would assist in heat loss and humidity would reach adequate levels.

The concentration of $\mathrm{CO}_{2}$ was greater than $\mathrm{NH}_{3}$, which perhaps had lower $\mathrm{S}_{\text {air }}$ values than those shown in Figure 3 (c) and (d), highlighting the importance of a ventilation system to enhance air quality. A further factor contributing to the prevalence of $\mathrm{CO}_{2}$ in both rearing phases is $\mathrm{CO}_{2}$ elimination by animals, which is directly influenced by thermogenesis and respiratory rates, being affected by high body weight and temperature (ATAKORA et al., 2011). In turn, $\mathrm{NH}_{3}$ arises from microbial decomposition (aerobic and anaerobic) and from excreted nitrogen compounds (feces and urine), being its emission rates, in the $\mathrm{F}$ phase, five times higher compared to the other categories (DÄMMGEN et al., 2013).

The $\mathrm{NH}_{3}$ concentrations shown in Figure 3 and Figure 4 (e) demonstrate existing relationship between this variable and $\mathrm{RH}$. Thus, one can observe that the highest contents of $\mathrm{NH}_{3}$ are linked directly to higher RH, as noted by MEDEIROS et al. (2014) in swine facilities. The emission levels of both $\mathrm{CO}_{2}$ and $\mathrm{NH}_{3}$ are similar to pigs in the $\mathrm{F}$ phase, while the corresponding values for the other categories vary more, especially for weaned piglets (PHILIPPE \& NICKS, 2015; PHILIPPE et al., 2011).

In short, it is important to note that pig farmers still find it difficult to provide a comfortable environment to the animals throughout the entire rearing. Currently, the vast majority of facilities are open, which makes difficult to control external environmental factors effectively and, the lack of internal cooling systems to maintain temperature, humidity and thermal sensation at suitable levels, providing the best performance of animal genetics allied to improved nourishment. The season of the year has also contributed to thermal stress in which the experiment was conducted, e.g. summer in the $\mathrm{F}$ phase.

\section{CONCLUSIONS}

Geostatistics enabled the identification of distinct environmental areas inside the pig farming facility under a wean-to-finish system, emphasizing the lack of environmental control. By this study, the most critical points, such as high temperatures, can be highlighted, emphasizing the need 
for nebulizer lines and fans. Heat stress could be observed during both analyzed rearing phases, however, with a satisfactory air quality level, which was primarily due to the ventilation system. Even though it was noted a few "dead spaces", the system was able to maintain levels within tolerable bounds.

\section{ACKNOWLEDGEMENTS}

The authors want to thank the FAPESP by research support, to the CNPq for scholarships granted to the authors, and to the Hamilton Abatti pig farm and to the Coperio (Cooperativa Rio do Peixe - Joaçaba, SC).

\section{REFERENCES}

ABREU, V. M. N.; ABREU, P. G. Os desafios da ambiência sobre os sistemas de aves no Brasil. Revista Brasileira de Zootecnia, Viçosa, MG, v.40, p.1-14, 2011.

AMARAL, A.G.; YANAGI JUNIOR, T.; LIMA, R.R.; TEIXEIRA, V.H.; SCHIASSI, L. Effect of the production environment on sexed broilers reared in a commercial house. Arquivo Brasileiro de Medicina Veterinária e Zootecnia, Belo Horizonte, v.63, n.3, p.649-658, 2011.

ATAKORA, J.K.A.; MOEHN, S.; BALL, R.O. Enteric methane produced by finisher pigs is affected by dietary crude protein content of barley grain based, but not by corn based, diets. Animal Feed Science Technology, New York, v.166-167, p.412-421, 2011.

BAPTISTA, R. I. A. A.; BERTANI, G. R.; BARBOSA, C. N. Indicadores do bem-estar em suínos. Ciência Rural, Santa Maria, v.41, n.10, p.1823-1830, 2011.

BARACHO, M.S.; TOLON, Y.B.; NAAS, I.A.; ROJAS. M. Sazonalidade da ambiência térmica, aérea e acústica em crèche e terminação de suínos. BioEng, Campinas, v.2.n.3, p.201212, set/dez.,2008.

BOURNET, P.E.; BOULARD, T. Effect of ventilator configuration on the distributed climate of greenhouses: A review of experimental and CFD studies. Computers and Electronics in Agriculture, New York, n.74, p.195-217, 2010.

CAMBARDELLA, C.A.; MOORMAN, T.B.; NOVAK, J.M.; PARKIN, T.B.; KARLEN, D.L.; TURCO, R.F.; KONOPKA, A.E. Field scale variability of soil properties in Central Iowa soils. Soil Science Society of America Journal, Madison, v.58, n.5, p.1501-1511, 1994.

CAMPOS, J. A.; TINÔCO, I. D. F. F.; da COSTA BAÊTA, F.; da SILVA, J. N.; CARVALHO, C. S.; MAUIRI, A. L. Ambiente térmico e desempenho de suínos em dois modelos de maternidade e creche. Ceres, Viçosa, MG, v.55, n.3, p. 187-193, 2008.

CARVALHO, T.M.R.; MOURA, D.J.; SOUZA, Z.M.; SOURA, G.S.; BUENO, L.G.B.; LIMA, K.A.O. Use of geostatistics on broiler production for evaluation of different minimum ventilation systems during brooding phase. Revista Brasileira Zootecnia, Viçosa, MG, v.41, n.1, p.194-202, 2012.

CARVALHO, V.F.; YANAGI JUNIOR, T.; FERREIRA, L.; DAMASCENO, F.A.; SILVA, M.P. Zoneamento do potencial de uso de sistemas de resfriamento evaporativo no sudeste brasileiro.

Revista Brasileira de Engenharia Agrícola e Ambiental, Campina Grande, v.13, n.3, p.358-366, 2009.

CASSUCE,D.C.;TINÔCO, I.F.F.; BAÊTA, F.C.; ZOLNIER, S.; CECON, P.R.; VIEIRA, M.F.A.Thermal comfort temperature update for broiler chickens up to 21 days of age. Engenharia Agrícola, Jaboticabal, v.33, n.1, p.28-36, 2013.

CORDEIRO, A.F.S.; NÄÄS, I.A.; STANLEY, R.M. OLIVEIRA, S.R.M.;VIOLARO, F.; ALMEIDA, A.C.M. Efficiency of distinct data mining algorithms for classifying stress level in piglets from their vocalization.Engenharia Agrícola, Jaboticabal, v.32, n.2, p.208-216, 2012. 
CURI, T.M.R.C.; VERCELLINO, R.A.; MASSARI, J.M; SOUZA, Z.M.; MOURA, D.J. Geoestatística para a avaliação do controle ambiental do sistema de ventilação em instalações comerciais para frangos de corte. Engenharia Agrícola, Jaboticabal, v.34, n.6, p.1062-1074, 2014.

DÄMMGEN, U.; BERK, A.; OTTEN, C.; BRADE, W.; HUTCHINGS, N.J.; HAENEL, H.D.; RÖSEMANN, C.; DÄNICKE, S.; LANDBAUFORSCH, M.S. Anticiped changes in the emissions of greenhoses gases and ammonia from pork production due to shifts from fattening of barrows towards fattening of boars. Applied Agricultural Forestry, Hannover, v.63, n.1, p.67-60, 2013.

GLOBALG.A.P. Integrated Farm Assurance. Poultry. Controls Point and Compliance Criteria. PY 5.4: 2011-2012, 2012. Disponível em: 〈www.globalgap.org〉. Acesso em: 24 fev. 2015.

MEDEIROS, B.B.L.; MASSARI, J.M.; MOURA, D.J.; CURI, T.M.R.C.; MAIA, A.P.A. uso da geoestatística na avaliação de variáveis ambientais em galpão de suínos criados em sistema "wean to finish" na fase de terminação. Engenharia Agrícola, Jaboticabal, v.34, n.5, p.800-811, 2014.

NÄÄS, I. A. Uso de técnicas de precisão na produção animal. Revista Brasileira de Zootecnia, Viçosa, MG, v. 40, p. 358-364, 2011 (supl. especial).

PANDORFI, H.; ALMEIDA, G. L.P.; GUISELINI, C. Zootecnia de precisão: princípios básicos e atualidades na suinocultura. Revista Brasileira de Saúde e Produção Animal, Salvador, v.13, n.2, p. 558-568, 2012.

PHILIPPE, F.X.; NICKS, B. Review on greenhouse gas emissions from pig houses: Production of carbon dioxide, methane and nitrous oxide by animals and manure. Agriculture, Ecosystems \& Environment, Amsterdam, v.199, p.10-25, 2015.

PHILIPPE, F.X., LAITAT, M., WAVREILLE, J., BARTIAUX-THILL, N., NICKS, B., CABARAUX, J.F., Ammonia and greenhouse gas emission from group-housed gestating sows depends on floor type. Agriculture Ecosystems \& Environment, Amsterdam, v.140, p.498-505, 2011.

RODRIGUES, N.E.B; ZANGERONIMO, M.G.; FIALHO, E.T. Adaptações fisiológicas de suínos sob estresse térmico. Texto Eletronico, Nutritime, Viçosa, MG, v.7, n.2, p.1197-1211, 2010.

SAMPAIO, C. A. P.; NÄÄS, I. A.; SALGADO, D. D. Amônia, gás sulfídrico, metano e monóxido de carbono na produção de suínos. Revista de Ciências Agroveterinárias, Lages, v.5, n.2, p.156 $164,2006$.

SAMPAIO, C.A.P.; CRISTANI, J.; DUBIELA, J.A.; BOFF, C.E.; OLIVEIRA, M.C. Avaliação do ambiente térmico em instalações para crescimento e terminação de suínos utilizando os índices de conforto térmico nas condições tropicais. Ciência Rural, Santa Maria, v.34, p.785-790, 2004.

SALES, F.A.; BARBOSA FILHO, J.A.D.; AQUINO, T.M.F.; BRITO, I.F.; CARVALHO, L.E. Monitoramento ambiental do perfil horizontal de um galpão para suínos, na fase de gestação, utilizando zootecnia de precisão. Revista Científica de Produção Animal, Paraíba, v.13, n.1, p.7$12,2011$.

SARUBBI, J.; ROSSI, L.A.; MOURA, D.J.; OLIVEIRA, R.A.; DAVID, E. Utilização de energia elétrica em diferentes sistemas de aquecimento para leitões desmamados. Revista Engenharia Agrícola, Jaboticabal, v.30, n.6, p.1003-1011, nov./dez. 2010.

SILVA, E.G.; SANTOS; A.C.; FERREIRA, C. L. S.; SOUSA, J. P. L.; ROCHA; J. M. L.; SILVEIRA JÚNIOR, O. Variabilidade espacial das características ambientais e peso de frangos de corte em galpão de ventilação negativa. Revista Brasileira de Saúde e Produção Animal, Salvador, v. 14, n. 1, p. 132-141, 2013.

SILVA NETO, S. P.; SILVA, R. G.; SANTOS A.C.; GAMA, F. R.; GUERRA, M. S.S.; BRITO, M. J. D. Padrões espaciais de deposição de fezes por bovinos de corte em áreas de paphasem.

Revista Brasileira de Saúde e Produção Animal, Salvador, v. 12, n. 2, p. 538-550, 2011. 
TOLON, Y.B.; BARACHO, M.S.; NAAS, I.A.; ROJAS, M.; MOURA, D.J. Ambiências térmica, aérea e acústica para reprodutores suínos. Engenharia Agrícola, Jaboticabal, v.30, n.1, p.1-13, 2010.

TRANGMAR, B. B.; YOST, R. S.; UEHARA, G. Application of geostatistics to spatial studies of soil properties. Advances in Agronomy, Newark, v.38, n.1, p.45-93, 1985.

VANNI, S.M. Modelos de regressão: estatística aplicada. São Paulo: Legmar Informática \& Editora, 1998. 177p.

VIEIRA, S.R. Geoestatística em estudos de variabilidade espacial do solo. In: NOVAIS, R.F.; ALVARES, V.H.; SCHAEFER, C.E.G.R. Tópicos em ciência do solo. Viçosa: Sociedade Brasileira de Ciência do Solo, 2000. v.1, p.1-53.

WARRICK, A.W.; NIELSEN, D.R. Spatial variability of soil physical properties in the field. In: HILLEL, D. (Ed.). Applications of soil physics. New York: Academic, 1980. p.319-376. 